\title{
INFLUENCE OF CLIMATE VARIABLES ON ROADKILL RATES OF WILD VERTEBRATES IN THE CERRADO BIOME, BRAZIL
}

\author{
INFLUÊNCIA DE VARIÁVEIS CLIMÁTICAS NAS TAXAS DE ATROPELAMENTO DE \\ VERTEBRADOS SILVESTRES NO BIOMA CERRADO, BRASIL
}

\author{
Carine Firmino CARVALHO'; Ana Elizabeth Iannini CUSTÓDIO²; \\ Oswaldo MARÇAL JÚNIOR ${ }^{1,2}$
}

1. Graduate Program in Ecology and Conservation of Natural Resources, Federal University of Uberlândia, MG, Brazil. carinefcarvalho@gmail.com; 2. Professor, Biology Institute, Federal University of Uberlândia, MG, Brazil.

\begin{abstract}
Wildlife road killing is a problem for animal conservation in the world. In order to mitigate this problem, it is necessary to understand the factors that affect it, like seasonality and climatic variables. The objective of the study was to evaluate the influence of climatic variables (mean temperature, relative air humidity and accumulated precipitation), seasonality and average daily traffic (ADT) on vertebrate roadkill rates in an area of Cerrado biome, Brazil. The study area is a stretch of $96 \mathrm{~km}$ of the highway BR-050, a four-lane road, between the cities of Uberlândia and Uberaba, state of Minas Gerais, Brazil. This area is characterized by intense fragmentation of natural areas, with few remnants of Cerrado biome. The climate has two very defined seasons, a warm and rainy summer and a very dry winter. We analyzed data from roadkill monitoring carried out from April 2012 to March 2013. The road was monitored weekly by car at an average speed of $60 \mathrm{~km} / \mathrm{h}$, by two observers, totaling $8,064 \mathrm{~km}$ surveyed. The highest roadkill rates for reptiles were recorded in the rainy season, for the other groups (mammals and birds) no difference was found. We also checked seasonality for the most abundant species: the highest number of roadkills was found in the rainy season for the common boa (Boa constrictor amarali) and for the six-banded armadillo (Euphractus sexcinctus). For the crab-eating fox (Cerdocyon thous), crab-eating raccoon (Procyon cancrivorus), striped hog-nosed skunk (Conepatus semistriatus) and red-legged seriema (Cariama cristata) we found no difference. The humidity and accumulated precipitation positively influenced the reptile roadkill rate. As expected, the same result was found for Boa constrictor amarali. Mammal roadkill rate increases with accumulated precipitation, on the other hand, Euphractus sexcinctus roadkill rate increases with temperature. Birds are not affected by climate variables, nevertheless, Cariama cristata roadkill rate decreases as humidity increases. Contrary to expectations, ADT had no influence on roadkill rates. These results show that it is necessary to investigate the influence of possible descriptor variables on mammals, birds and reptiles separately and not for all vertebrates as a group. Furthermore, certain species may even present different temporal patterns.
\end{abstract} collision.

KEYWORDS: Humidity. Precipitation. Road Ecology. Seasonality. Temporal patterns. Wildlife vehicle

\section{INTRODUCTION}

Studies about fauna roadkill have been highlighted worldwide (FORMAN; ALEXANDER, 1998; COELHO et al., 2008; GRILO et al., 2010; D'AMICO et al., 2015; TEIXEIRA et al., 2017). In Brazil, Road Ecology have had a rapid growth since 2004 (BAGER et al., 2015). On the other hand, knowledge about the impact of roads on wildlife is still limited, being produced mainly from sporadic observations (DORNAS et al., 2012), making it difficult to evaluate the effect of mortality on population persistence (BAGER et al., 2015; TEIXEIRA et al., 2016). According to the latest survey carried out in the country, over 475 million animals die per year due to accidents with vehicles (CBEE, 2017). This estimate shows the urgent need to carry out systematic studies addressing this important cause of biodiversity loss in order to provide data that can be used in the implementation of mitigation measures and environmental planning (GLISTA et al., 2009; GRILO et al., 2010; LESBARRÈRES; FAHRIG, 2012).

It is necessary to understand better the factors that influence roadkill to implement efficient mitigation measures. In Europe, USA and Canada some studies tried to understand this (CLEVENGER et al., 2003; GRILO et al., 2009; GRILO et al., 2012; D'AMICO et al., 2015; GARRIGA et al., 2017) and concluded that temperature influences roadkill (D'AMICO et al., 2015; GARRIGA et al., 2017). In Brazil, we have just started, our researches investigate if there are more roadkill in the rainy or dry season (BUENO; ALMEIDA, 2010; RAMOS et al., 2011; ROSA; BAGER, 2012; BRAZ; FRANÇA, 2016) or the stretches of the highway with higher roadkill rates (CÁCERES et al., 2012; BUENO et al., 2012; SANTANA, 2012; FERREIRA et al., 2014; CARVALHO et al., 2015; ASCENSÃO et al., 2017; SANTOS et al., 2017). We still need to 
understand better the influence of climate variables on roadkill in tropical countries, such as Brazil.

Concerning seasonality, some authors have reported a higher frequency of vertebrate roadkill in the dry season (MELO; SANTOS-FILHO, 2007; TURCI; BERNARDE, 2009; BUENO; ALMEIDA, 2010). These authors believe that there is an increase in roadkill accidents in the dry season due to lack of resources, which would increase the mobility of animals and, consequently, the roadkill rates on highways. On the other hand, some authors have found no difference on vertebrate roadkill rates between seasons (MILLI; PASSAMANI, 2006; HENGEMÜHLE; CADEMARTORI 2008; CUNHA et al., 2010) or a higher roadkill rate in the wet season (BRAZ; FRANÇA, 2016). Still, the majority of the studies investigate the vertebrates as a group or examine mammals alone. However, are there differences in the response to climate variables depending on the group studied? Our hypotheses are: 1 - only reptile roadkill rates are influenced by climate variables and seasonality; 2 - roadkill rates of all groups are influenced by vehicle flow. Under this perspective, we developed this study to evaluate the influence of climate variables on roadkill rates of wild animals on a highway located in the domain of Cerrado.

\section{MATERIAL AND METHODS}

\section{Study Area}

The study area is located in an area of Cerrado biome characterized by intense fragmentation of natural habitats (forests, cerrado sensu stricto, and 'veredas' or palm swamps), which have been replaced by pastures and crops, the dominant characteristics of the landscape surrounding the highway (CARVALHO et al., 2015). The climate according to the Köppen classification is Aw, showing seasonal traits with rain in the summer and a dry winter; average temperatures range between $17^{\circ} \mathrm{C}$ and $23^{\circ} \mathrm{C}$, annual temperature range between $7^{\circ} \mathrm{C}$ and $9^{\circ} \mathrm{C}$ and relative humidity of the air range between 40 and $80 \%$ (ROSA et al., 1991).

The highway BR-050, with 1,094 kilometers $(\mathrm{km})$ of extension, is a Brazilian federal highway and as such, it is an important means of connection between the Federal District and the Brazilian states of Goiás, Minas Gerais, and São Paulo. The study was carried out on the stretch of the highway between the cities of Uberlândia and Uberaba, in Minas Gerais state (initial coordinates S18 54'304', Wo48 13'347', final coordinates S19 $44^{\circ} 485^{\prime \prime}$ Wo47 $\left.58^{\prime} 575^{\prime \prime}\right)$. This stretch of the highway has approximately $96 \mathrm{~km}$ and is four-lane road (Figure 1).

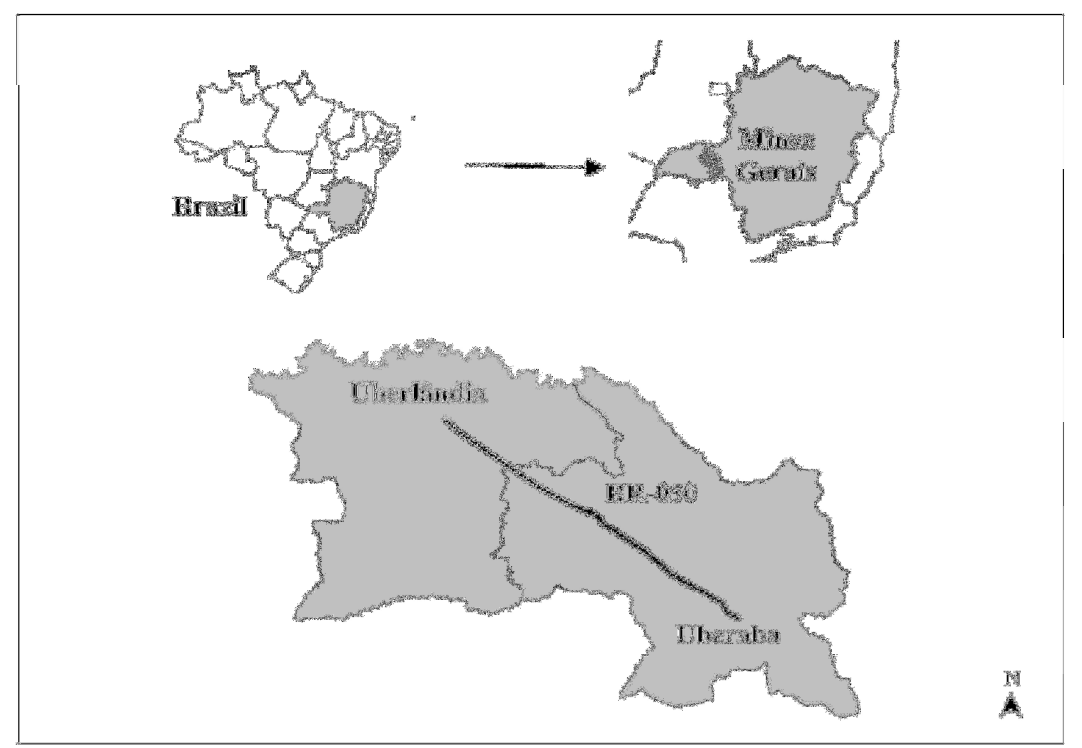

Figure 1. Study area, highlighting the stretch of the highway BR-050, between the cities of Uberlândia and Uberaba, State of Minas Gerais, Brazil.

\section{Procedures}

We analyzed the dataset from one year of research produced by Carvalho et al. (2015). This monitoring was done by car, weekly, from April 2012 to March 2013, totaling 8,064 km. Due to the high traffic of vehicles on the road we used a speed of approximately $60 \mathrm{~km} / \mathrm{h}$. Two observers examined each kilometer of the road looking for roadkill and registering the geographical positions of the carcasses. 
Individuals that could not be identified at specific level, due to the advanced stage of decomposition, were classified as indeterminate and recorded for analysis only when it could be discriminated whether or not they were wild species. Carcasses were removed from the highway to avoid later recounts. The Climatological Station of the Federal University of Uberlândia, Minas
Gerais state, Brazil, provided the climate variables data (means values of temperature, relative air humidity and accumulated precipitation) (Figure 2). The National Department of Transportation Infrastructure (Departamento Nacional de Infraestrutura de Transportes - DNIT, in Portuguese) provided the average daily traffic data (ADT) (Figure 3).

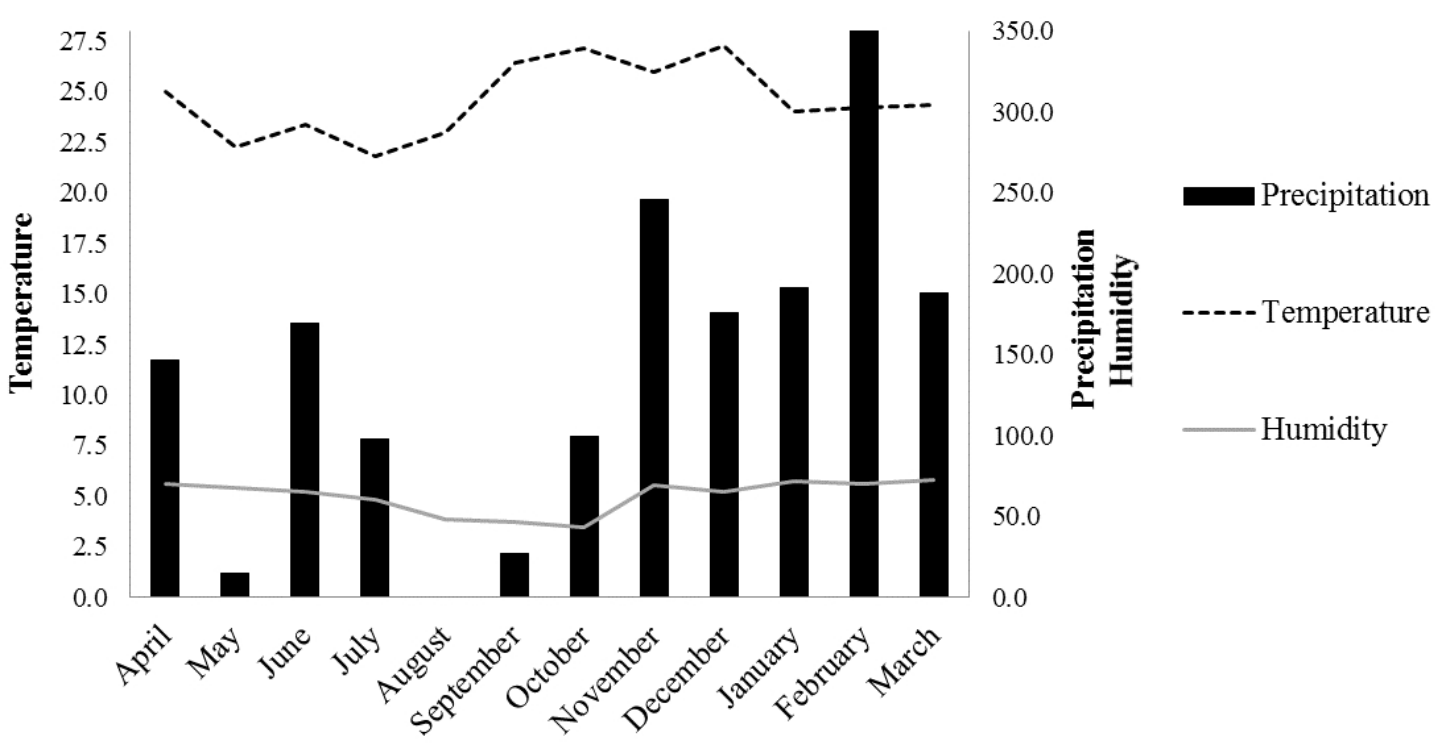

Figure 2. Meteorological data for the region of Uberlândia (2012-2013). Source: Climatological Station of the Federal University of Uberlândia (UFU), Brazil.

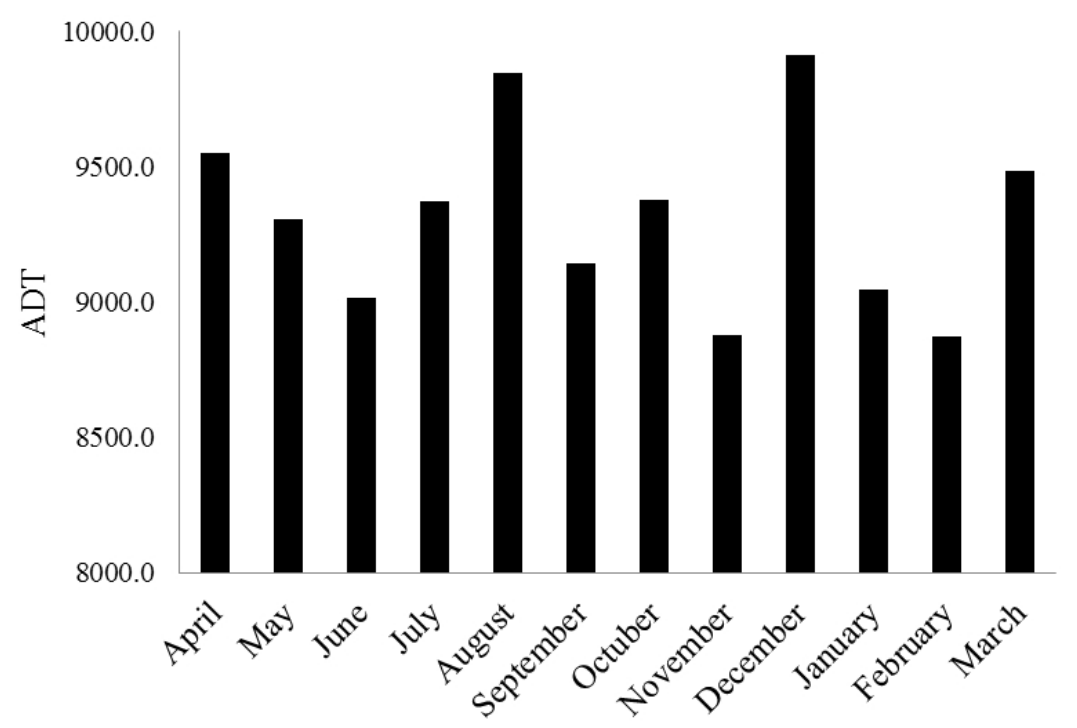

Figure 3. Average daily traffic (ADT) for the stretch of the BR-050 highway between Uberlândia and Uberaba, Brazil (2012-2013). Source: National Department of Transportation Infrastructure (DNIT).

\section{Data Analysis}

We tested differences in daily roadkill rate between the dry and rainy seasons using the t test for two samples ( $t$ ) when data was normal or the
Mann-Whitney (U) test in the case of non-normal data. For the region, the rainy season comprise the months from October to April, the dry season the months from May to September (ROSA et al., 
1991). We performed these analyses for the taxonomic groups (mammals, birds and reptiles), for the most abundant species (common boa Boa constrictor amarali, six-banded armadillo Euphractus sexcinctus, red-legged seriema Cariama cristata, crab-eating fox Cerdocyon thous, crabeating raccoon Procyon cancrivorus, and striped hog-nosed skunk Conepatus semistriatus), and for the climate variables and for ADT. We also analyzed in which months there were less and more roadkill events than expected by chance using the Poisson test - in these analyses we multiplied the roadkill rate (individuals $/ \mathrm{km} / \mathrm{month}$ ) per 100 .

Possible correlations between climate variables (mean temperature, humidity and accumulated precipitation), ADT and the daily roadkill rates were tested by the Spearman correlation (rs). We ran all the tests on R 3.4 ( $\mathrm{R}$ Core Team 2017).

\section{RESULTS}

The roadkill rates were higher in the rainy season for reptiles $(\mathrm{U}=86.5, \mathrm{p}=0.001)$, Boa constrictor amarali $(\mathrm{U}=118.0, \mathrm{p}=0.005)$ and Euphractus sexcinctus $(\mathrm{U}=107, \mathrm{p}=0.005)$. We detected no difference between the seasons for mammals ( $\mathrm{U}=195.0, \mathrm{p}=0.761)$, birds $\quad(\mathrm{U}=164$, $\mathrm{p}=0.258)$, Cerdocyon thous $(\mathrm{U}=176.5, \mathrm{p}=0.405)$, Procyon cancrivorus $(\mathrm{U}=212.5, \quad \mathrm{p}=0.873)$, Conepatus semistriatus $(\mathrm{U}=263.0, \mathrm{p}=0.123)$ and Cariama cristata $(\mathrm{U}=267.5, \mathrm{p}=0.060)$ (Figure 4).

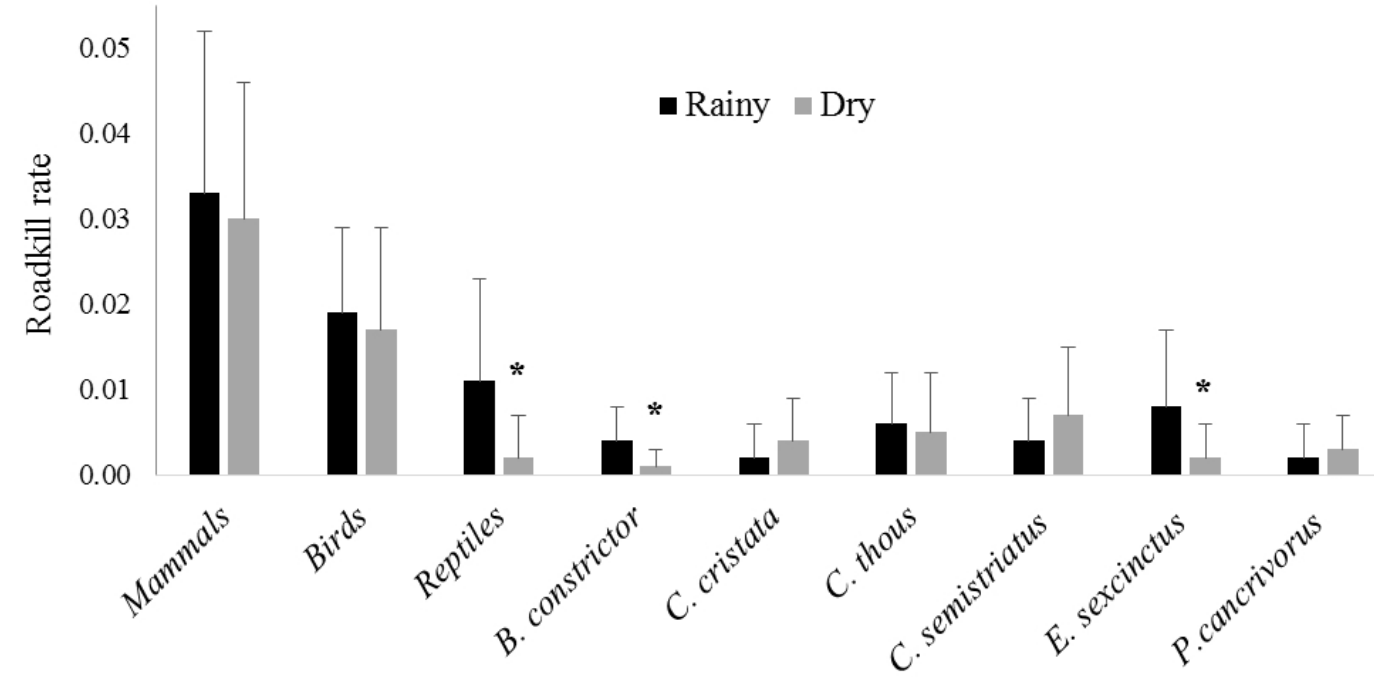

Figure 4. Roadkill rate (animals/km/day) for the rainy and dry seasons. The asterisk in bold means significant difference.

For mammals, the months with the highest roadkill rates were April, May and December $(\mathrm{p}<0.05$, Poisson test indicates months with more than 118 specimens $/ \mathrm{km} /$ month*100); the ones with the lowest rates were August, September, October and February $(\mathrm{p}<0.05$, Poisson test indicates months with less than 85 specimens $/ \mathrm{km} / \mathrm{month} * 100$ ) (Figure 5). For birds, October and January were the months with the greatest numbers of roadkill $(\mathrm{p}<0.05$, Poisson test indicates months with more than 66 specimens $\left./ \mathrm{km} / \mathrm{month}^{*} 100\right)$; April and November were the ones with the smallest numbers $(p<0.05$, Poisson test indicates months with less than 42 specimens $/ \mathrm{km} / \mathrm{month} * 100)$. For reptiles, the highest incidence of roadkill was in the months of March, April and November $(\mathrm{p}<0.05$, Poisson test indicates months with more than 28 specimens $/ \mathrm{km} /$ month*100); May, July, August, September and October were the months with the lowest incidence $(\mathrm{p}<0.05$, Poisson test indicates months with more than 13 specimens $/ \mathrm{km} /$ month*100).

The relative humidity of the air $(\mathrm{U}=101$, $\mathrm{p}=0.006)$, the accumulated precipitation $(\mathrm{U}=89$, $\mathrm{p}=0.002)$ and the temperature $(\mathrm{t}=-3.25 \mathrm{p}=0.003)$ were higher in the months of the rainy season. ADT $(\mathrm{t}=0.887, \mathrm{p}=0.381)$ was not influenced by these seasons. There are more Euphractus sexcinctus roadkills in high temperatures. As humidity increases, the roadkill rate of reptiles and Boa constrictor amarali also increases, but the Cariama cristata roadkill rate decreases. The higher the precipitation, the higher is the roadkill rate for mammals, reptiles and Boa constrictor amarali. Humidity and Precipitation are highly correlated. ADT has no influence on the groups, species or climate variables (Table 1). 
Mammals

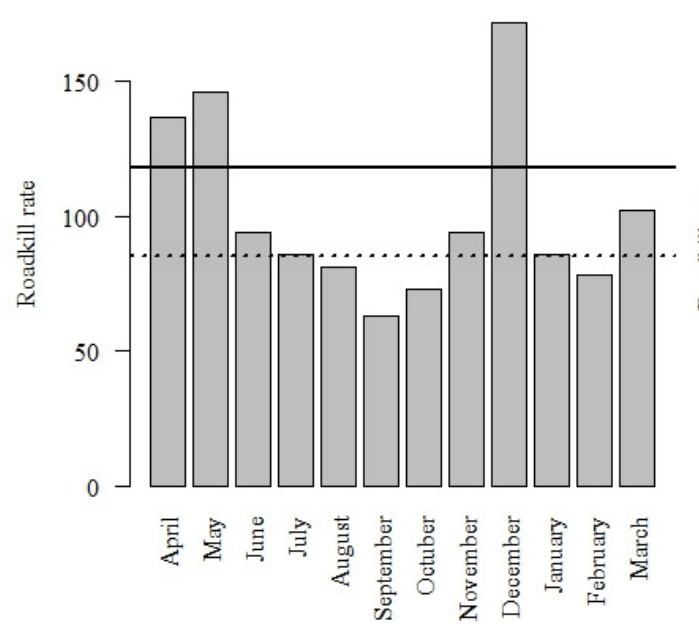

Reptiles

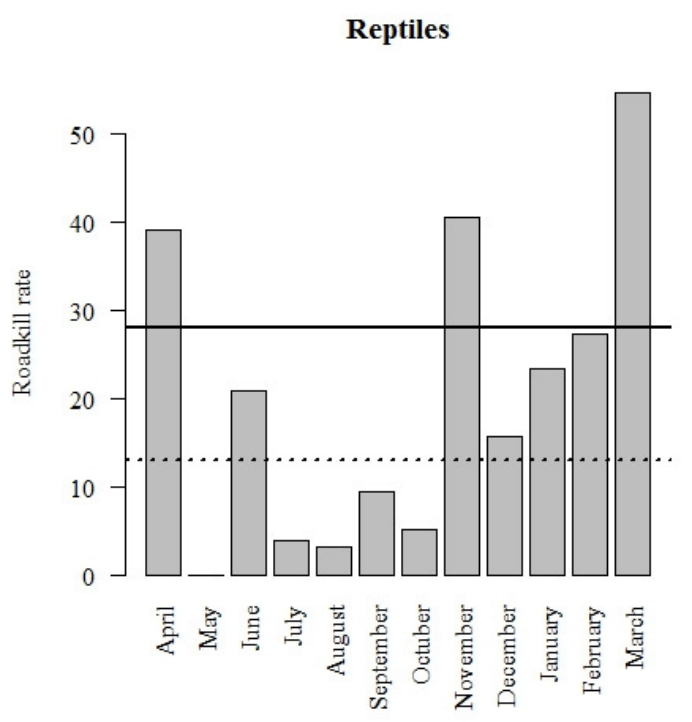

Birds

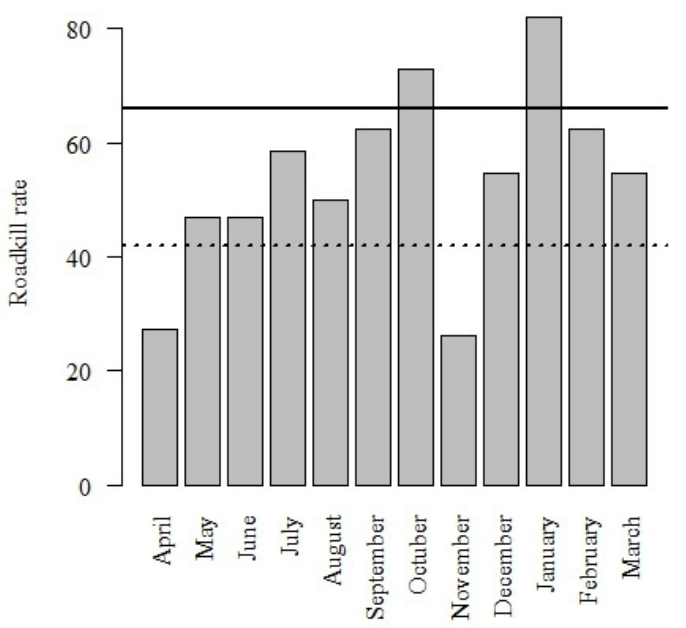

Figure 5. Monthly roadkill rate for the taxonomic groups (specimens $/ \mathrm{km} / \mathrm{month} * 100)$ ). Dotted line - months under this line have less roadkill events than expected by chance. Straight line - months above this line have more roadkill events than expected by chance.

Table 1. Spearman correlation indexes among the variables.

\begin{tabular}{llllr}
\hline & Temperature & Humidity & Precipitation & ADT \\
\hline Mammals & -0.03 & 0.30 & $0.37^{*}$ & 0.06 \\
Birds & 0.04 & -0.04 & 0.06 & -0.20 \\
Reptiles & 0.29 & $0.42^{* *}$ & $0.35^{*}$ & -0.11 \\
Boa constrictor amarali & 0.18 & $0.46^{* *}$ & $0.46^{* *}$ & -0.05 \\
Cariama cristata & 0.11 & $-0.38^{*}$ & -0.20 & 0.03 \\
Cerdocyon thous & 0.04 & 0.12 & 0.23 & 0.00 \\
Conepatus semistriatus & -0.23 & 0.14 & 0.19 & 0.06 \\
Euphractus sexcinctus & $0.51^{* *}$ & 0.01 & 0.11 & 0.08 \\
Procyon cancrivorus & -0.12 & 0.15 & 0.02 & 0.14 \\
Temperature & 1.00 & -0.25 & 0.03 & -0.19 \\
Humidity & -0.25 & 1.00 & $0.75^{* *}$ & -0.07 \\
Precipitation & 0.03 & $0.75^{* *}$ & 1.00 & -0.19 \\
ADT & -0.19 & -0.07 & -0.19 & 1.00 \\
\hline
\end{tabular}




\section{DISCUSSION}

Reptiles showed higher roadkill rates in the rainy season, but these rates did not vary for mammals and birds, which supports our first hypothesis. Freitas (2009) and Santana (2010) also observed higher occurrences of reptile roadkill in the rainy season. Santos et al. (2017), like us, reported a higher roadkill rate in the months of the rainy season. D'Amico and colleagues (2015), in Europe, concluded that snake roadkill increases with higher temperatures. $\mathrm{We}$ found a positive correlation among reptile roadkill, humidity and precipitation, which seems to explain why we have higher roadkill rates for this group in the rainy months. Therefore, a higher roadkill rate in the rainy season for Boa constrictor amarali was also expected.

According to Rosa and colleagues (2012), birds and mammals of medium and large size suffer less influence of climate variation than reptiles and amphibians. The same was observed by Milli and Passamani (2006) and Ramos and colleagues (2011). Rosa and Bager (2012) reported higher bird roadkill rates in summer and autumn, consistent with Santos et al. (2017), who detected more bird roadkills in the rainy months. The issue with our results is that we have rainy/dry months with more and less roadkills than expected, which makes it difficult to make any inference about bird temporal patterns.

Hegel and colleagues (2012) and Cáceres and colleagues (2012) found more mammal roadkills in the rainy season. On the other hand, Bueno and Almeida (2010) research found more roadkills in the dry season. Although we did not find seasonality for mammals, in general the rainy months produced more roadkills and the dry months less. This may have happened because of the influence of precipitation in mammal roadkill. Leite and colleagues (2012), found a positive correlation between wild mammal roadkill and temperature in the south Brazil. Hegel and colleagues (2012) and Santana (2010) did not find correlations between wild mammal roadkill and climate variables.

Gumier-Costa and Sperber (2009) suggest that the correlations between climatic variables and roadkill may result from the synchronization of the flowering and fruiting of various plant species, which increase the activity and movement of the fauna. These results may also be related to bionomic aspects of the respective species (birth, provisioning for young, foraging, dispersal and reproduction), which vary from one species to another (GRILO et al. 2009). Despite not finding seasonality for mammals we found more Euphractus sexcinctus roadkills in the rainy season, also, high temperature increases this species' roadkill. Maccarani and colleagues (2015) concluded that for Euphractus sexcinctus, in the Pantanal wetlands of Brazil, the mean activity onset increases with temperature, but temperature decreases the activity duration. This may suggest that in high temperatures this species will extend the activity through the night, increasing their roadkill probability. Cariama cristata roadkill rate is lower when the humidity values are high, which may explain why the roadkill rate is nearly significantly higher for this species in the dry season. Therefore, it is necessary to understand better the life history of these species to explain why there are higher roadkill rates in a certain period of the year for some species but not for others.

The temporal variation in roadkill taxa and rates may be related to the differences in vehicular traffic and increased mobility and/or abundance of fauna during certain periods of the year, which may include reproduction and dispersion seasons, temporal variations of landscape features and availability of resources (COELHO et al. 2008). In the present study, contrary to expected, no correlation was found between the average daily traffic (ADT) and the wildlife roadkill rate. Likewise, Bueno \& Almeida (2010) discovered no correlation between wild mammal roadkill and ADT. Coelho and colleagues (2008) identified a positive correlation between these variables, justifying that the period of increased vehicle flow coincides with the higher activity of the reptiles. We believe that the absence of influence of climatic conditions on the ADT in our study area explains the results obtained.

In summary, it seems that reptile roadkill rates are influenced by season and climate variables. The correlation between climate variables and roadkill suggest that climate variables are some of the parameters that explain why we have more roadkills in the rainy season for reptiles. For mammals and birds, the correlation is not clear yet. Our data indicates that mammal roadkills are influenced by precipitation, causing higher roadkill rates in the rainy season. Still, the temporal patterns exhibited by some species may be different from those of other taxa, therefore more researches are necessary to understand roadkill temporal patterns and plan efficient mitigation measures. Finally, it is necessary to investigate the influence of possible descriptor variables on mammals, birds and reptiles separately and not together as one group (vertebrates). Also, certain species may present different temporal patterns. 


\section{ACKNOWLEDGEMENT}

To CAPES for granting the scholarship to the main author of this work and everyone who helped in any way in the execution of this research.

RESUMO: O atropelamento de animais selvagens é um problema para a conservação da fauna no mundo. Para mitigar esse problema é necessário entender os fatores que o influenciam, como sazonalidade e variáveis climáticas. $\mathrm{O}$ objetivo do estudo foi avaliar a influência das variáveis climáticas (temperatura, umidade relativa do ar e precipitação acumulada), sazonalidade e volume diário médio de veículos (VDM) nas taxas de atropelamento de vertebrados em uma área do bioma Cerrado, Brasil. A área de estudo é um trecho de $96 \mathrm{~km}$ da rodovia BR-050, rodovia duplicada, entre as cidades de Uberlândia e Uberaba, Minas Gerais, Brasil. Essa área é caracterizada por intensa fragmentação dos habitats naturais com poucos remanescentes do bioma Cerrado. O clima apresenta sazonalidade com chuva no verão e seca no inverno. Foram analisados dados de monitoramento de atropelamento realizados de abril de 2012 a março de 2013 . A rodovia foi monitorada semanalmente, de carro, a uma velocidade média de $60 \mathrm{~km} / \mathrm{h}$, por dois observados, totalizando $8.064 \mathrm{~km}$ vistoriados. As maiores taxas de atropelamento para répteis foram encontradas na estação chuvosa; para os outros grupos (mamíferos e aves) nenhuma diferença foi encontrada. Também foi verificada sazonalidade para as espécies mais abundantes: um maior número de atropelamentos foi encontrado na estação chuvosa para a jiboia (Boa constrictor amarali), assim como para o tatu-peba (Euphractus sexcinctus). Para o cachorro-do-mato (Cerdocyon thous), o mãopelada (Procyon cancrivorus), a jaritataca (Conepatus semistriatus) e a seriema (Cariama cristata) nenhuma diferença foi encontrada. A humidade e a precipitação acumulada influenciaram positivamente a taxa de atropelamento de répteis. Como esperado, o mesmo resultado foi encontrado para Boa constrictor amarali. A taxa de atropelamento de mamíferos aumenta com a precipitação acumulada; por outro lado, a taxa de atropelamento de Euphractus sexcinctus aumenta com a temperatura. Aves não são afetadas pelas variáveis climáticas, não obstante, a taxa de atropelamento de Cariama cristata diminuiu com o aumento da humidade. Contrário às expectativas, o VDM não influencia as taxas de atropelamento. Esses resultados mostram que é necessário investigar a influência de possíveis variáveis descritoras para mamíferos, aves e répteis separadamente, e não para todos os vertebrados como um só grupo. Além disso, algumas espécies podem apresentar diferentes padrões temporais.

PALAVRAS-CHAVE: Colisão de animais selvagens com veículos. Ecologia de estradas. Humidade. Padrões temporais. Precipitação. Sazonalidade.

\section{REFERENCES}

ASCENSÃO, F.; DESBIEZ, A. L. J.; MEDICI, E. P.; BAGER, A. Spatial patterns of road mortality of medium-large mammals in Mato Grosso do Sul, Brazil. Wildlife Researche,v. 44, n. 2, p 135- 146, jun 2017. https://doi.org/10.1071/WR16108

BAGER, A.; FONTOURA, V. Ecologia de estradas no Brasil- Contexto histórico e perspectivas futuras. In: BAGER, A. (ed.) Ecologia de Estradas: tendências e pesquisas. Lavras: Ed. UFLA, p. 13-33, 2012. https://doi.org/10.1002/9781118568170.ch50

BAGER, A.; BORGHI, C. E.; SECCO, H. The Influence of Economics, Politics and Environment on Road Ecology in South America. In: VAN DER REE, R.; SMITH, D. J.; GRILO, C (eds.). Handbook of Road Ecology, John Wiley \& Sons Ltd., p. 407-413, 2015.

BRAZ, V. DA S.; FRANÇA, F. G. R. Wild vertebrate roadkill in the Chapada dos Veadeiros National Park, Central Brazil. Biota Neotropica, v. 16, n. 1, p. 1-11, 2016. https://doi.org/10.1590/1676-0611-BN-2014-0182

BUENO, C.; ALMEIDA, P. J. A. L. de. Sazonalidade de atropelamentos e os padrões de movimentos em mamíferos na BR-040 (Rio de Janeiro-Juiz de Fora). Revista Brasileira de Zoociências, v. 12, p. 219-226, 2010. 
BUENO, C.; FREITAS, L. E.; COUTINHO, B. H. OSWALDO CRUZ, J. H. CASTRO JÚNIOR, E. de. A distribuição especial de atropelamentos de fauna silvestre sua relação com a vegetação: Estudo de caso da rodovia BR-040. In: BAGER, A. (ed.) Ecologia de Estradas: tendências e pesquisas. Lavras: Ed. UFLA, p. 13-33, 2012.

CÁCERES, N. C.; CASELLA, J.; GOULART, C. S. Variação espacial e sazonal de atropelamentos e mamíferos no bioma cerrado, rodovia BR 262, Sudoeste do Brasil. Mastozoología Neotropical, Mendoza, v. 19, n. 1, p. 21-33, 2012.

CARVALHO, C. F.; IANNINI CUSTODIO, A. E.; MARCAL JUNIOR, O. Wild Vertebrates Roadkill Aggregations on the Br-050 Highway, State of Minas Gerais, Brazil. Bioscience Journal, v. 31, n. 3, p. 951959, 2015. https://doi.org/10.14393/BJ-v31n3a2015-27468

CBEE. (2017) Atropelômetro. Disponível em: http://cbee.ufla.br/portal/atropelometro/. Acesso em: 20.05.2017.

CLEVENGER, A. P; CHRUSZCZ, B.; GUNSON, K. E. Spatial patterns and factors influencing small vertebrate fauna road-kill aggregations. Biological Conservation, v. 109, p. 15-26, 2003. https://doi.org/10.1016/S0006-3207(02)00127-1

COELHO, I. P.; KINDEL, A.; COELHO, A. V. P. Roadkills of vertebrate species on two highways through the Atlantic Forest Biosphere Reserve, southern Brazil. European Journal of Wildlife Research, v. 54, n. 4, p. 689-699, 3 jul. 2008. https://doi.org/10.1007/s10344-008-0197-4

CUNHA, H. F.; MOREIRA, F. G. A.; SILVA, S. de S. Roadkill of wild vertebrates along the GO-060 road between Goiânia and Iporá, Goiás State, Brazil. Acta Scientiarum Biological Sciences, Maringá, v. 32, n. 3, p. 257-263, 2010.

D’AMICO, M. ; ROMÁN, J.; REYS, L.; REVILLA, E. Vertebrate road-kill patterns in Mediterranean habitats: Who, when and where. Biological Conservation, v. 191, n. November, p. 234-242, 2015. https://doi.org/10.1016/j.biocon.2015.06.010

DORNAS, R. A. P; KINDEL, A.; BAGER, A.; FREITAS, S. R. Avaliação da mortalidade de vertebrados em rodovias. In: BAGER, A. (ed.) Ecologia de Estradas: tendências e pesquisas. Lavras: Ed. UFLA, p. 139-152. 2012.

FERREIRA, C. M. M. et al. Variação espacial de atropelamentos de mamíferos em área de restinga no estado do Espírito Santo, Brasil. Neotropical Biology and Conservation, v. 9, n. 3, p. 125-133, 2014. https://doi.org/10.4013/nbc.2014.93.02

FORMAN, R. T. T.; ALEXANDER, L. E. Roads and Their Major Ecological Effects. Annual Review of Ecology and Systematics, v. 29, n. 1, p. 207-231, nov. 1998. https://doi.org/10.1146/annurev.ecolsys.29.1.207

FREITAS, C. H. 2009. Atropelamento de vertebrados nas rodovias MG-428 e SP-334 com análise dos fatores condicionantes e valoração econômica da fauna. Tese de doutorado - Universidade Estadual Paulista, Rio Claro. 2009.

GARRIGA, N.; FRANCH, M.; SANTOS, X.; MONTORI, A.; LLORENTE, G. A. Seasonal variation in vertebrate traffic casualties and its implications for mitigation measures. Landscape and Urban Planning, v. 157, p. 36-44, 2017. https://doi.org/10.1016/j.landurbplan.2016.05.029

GLISTA, D. J.; DEVAULT, T. L.; DEWOODY, J. A. A review of mitigation measures for reducing wildlife mortality on roadways. Landscape and Urban Planning, v. 91, n. 1, p. 1-7, maio 2009. https://doi.org/10.1016/j.landurbplan.2008.11.001 
GRILO, C.; BISSONETTE, J. A.; SANTOS-REIS, M. Spatial-temporal patterns in Mediterranean carnivore road casualties: Consequences for mitigation. Biological Conservation, v. 142, p. 301-313, 2009. https://doi.org/10.1016/j.biocon.2008.10.026

GRILO, C.; BISSONETTE, J. A.; CRAMER, P. C. Mitigation measures to reduce impacts on biodiversity. In: JONES, R. S (ed.). Highways: constructions, management and maintenance. Nova Science Publishers, p. 73-114, 2010.

GRILO, C.; SOUSA, J.; ASCENSÃO, F.; MATOS, H.; LEITÃO, I.; PINHEIRO, P.; COSTA, M.; BERNARDO, J.; RETO, D.; LOURENÇO, R.; SANTOS-REIS, M.; REVILLA, E. Individual spatial responses towards roads: implications for mortality risk. PloS One, v. 7, n. 9, p 1-11, sep. 2012.

https://doi.org/10.1371/journal.pone.0043811

GUMIER-COSTA, F.; SPERBER, C. F. Atropelamentos de vertebrados na Floresta Nacional de Carajás, Pará, Brasil. Acta Amazoniaca, v. 39, n. 2, p. 459-466, 2009. https://doi.org/10.1590/S0044-59672009000200027

HEGEL, C. G. Z.; CONSALTER, G. C.; ZANELLA, N. Mamíferos silvestres atropelados na rodovia RS-135, norte do Estado do Rio Grande do Sul. Biotemas, v. 25, n. 2, p. $165-$ 170, 2012. https://doi.org/10.5007/2175-7925.2012v25n2p165

HENGEMÜHLE, A.; CADEMARTORI, C. V. Levantamento de mortes de vertebrados silvestres devido a atropelamento em um trecho da estrada do mar (RS-389). Biodiversidade Pampeana, v. 6, n. 2, p. 4-10, 2008.

LEITE, R. M. S.; BÓÇON, R.; BELÃO, M. SILVA, J. C. Atropelamento de mamíferos silvestres de médio e grande porte nas rodovias PR-407 e PR-508, Planície Costeira do estado do Paraná, Brasil. In: BAGER, A. (ed.) Ecologia de Estradas: tendências e pesquisas. Lavras: Ed. UFLA, p. 139-152. 2012.

LESBARRÈRES, D.; FAHRIG, L. Measures to reduce population fragmentation by roads: what has worked and how do we know? Trends in ecology \& evolution, v. 27, n. 7, p. 374-80, jul. 2012.

ttps://doi.org/10.1016/j.tree.2012.01.015

MACCARINI, T. B.; ATTIAS, N.; MEDRI, I. M.; MARINHO-FILHO, J.; MOURÃO, G. Temperature influences the activity patterns of armadillo species in a large neotropical wetland. Mammals Research, v. 60, n. 4, p. 403-409, out. 2015. https://doi.org/10.1007/s13364-015-0232-2

MELO, E. S.; SANTOS-FILHO, M. Efeitos da BR-070 na Província Serrana de Cáceres, Mato Grosso, sobre a comunidade de vertebrados silvestres. Revista brasileira de Zoociências, v. 9, n. 2, p. 185-192, 2007.

MILLI, M. S.; PASSAMANI, M. Impacto da Rodovia Josil Espíndula Agostini (ES-259) sobre a mortalidade de animais silvestres (Vertebrata) por atropelamento. Natureza on line, v. 4, n. 2, p. 40-46, 2006.

R Core Team (2017). R: A language and environment for statistical computing. R Foundation for Statistical Computing, Vienna, Austria. Disponível em <https://www.R-project.org/>.

RAMOS, C. C. O.; LIMA JÚNIOR, D. P.; ZAWADZKI, C. H.; BENEDITO, E. A biologia e a ecologia das aves é um fator importante para explicar a frequência de atropelamentos ? Neotropical Biology and Conservation, v. 6, p. 201-212, 2011.

ROSA, R., LIMA, S. C., ASSUNÇÃO, W. L. Abordagem preliminar das condições climáticas de Uberlândia (MG). Sociedade e natureza, v. 3, p. 91-108, 1991.

ROSA, C. A.; CARDO, T. R.; TEIXEIRA, F. Z.; BAGER, A. Atropelamento de fauna selvagem: amostragem e análise de dados em ecologia de estradas. In: BAGER, A. (ed.) Ecologia de Estradas: tendências e pesquisas. Lavras: Ed. UFLA, p. 79-99. 2012. 
ROSA, C. A.; BAGER, A. Seasonality and habitat types affect roadkill of Neotropical birds. Journal of environmental management, v. 97, p. 1-5, 30 abr. 2012. https://doi.org/10.1016/j.jenvman.2011.11.004

SANTANA, G. S. Fatores influentes sobre atropelamentos de vertebrados na região central do Rio Grande do Sul, Brasil. Neotropical Biology and Conservation, v. 7, n. 1, p. 26-40, 2012. https://doi.org/10.4013/nbc.2012.71.05

SANTOS, R. A. L.; ASCENSÃO, F.; RIBEIRO, M. L.; BAGER, A.; SANTOS-REIS, M.; AGUIAR, L. M. S. Assessing the consistency of hotspot and hot-moment patterns of wildlife road mortality over time.

Perspectives in Ecology and Conservation, v. 15, n. 1, p. 56-60, 2017.

https://doi.org/10.1016/j.pecon.2017.03.003

TEIXEIRA, F. Z.; COELHO, I. P.; LAUXEN, M.; ESPERANDIO, I. B.; HARTIZ, S. M.; KINDEL, A. The need to improve and integrate science and environmental licensing to mitigate wildlife mortality on roads in Brazil. Tropical Conservation Science, v. 9, n. 1, p. 34-42, 2016.

https://doi.org/10.1177/194008291600900104

TEIXEIRA, F. Z.; KINDELL, A.; HARTZL, S. M.; MITCHELL, S.; FAHRIG, L. When road-kill hotspots do not indicate the best sites for road-kill mitigation. Journal of Applied Ecology, 2017.

TURCI, L. C. B.; BERNANDE, P. S. Vertebrados atropelados na Rodovia Estadual 383 em Rondônia, Brasil. Biotemas, v. 22, n. 1, p. 121-127, 2009. https://doi.org/10.5007/2175-7925.2009v22n1p121 